\title{
ALEXIS O EL TRATADO DEL INÚTIL COMBATE: CRISIS DE LA MASCULINIDAD Y CONFORMACIÓN DE LAS IDENTIDADES MASCULINAS
}

\author{
ALEXIS OR THE COMBAT USELESS TREATY: MASCULINITY CRISIS AND MASCULINE \\ IDENTITY CONFORMATION **
}

\section{Carla Rodríguez Corrales*}

\begin{abstract}
RESUMEN
Este artículo constituye una aproximación a la novela de la escritora francesa Marguerite Yourcenar titulada Alexis o el Tratado del inútil combate (1929). En este espacio se establece un diálogo entre la propuesta literaria del texto, la (des) configuración de su personaje Alexis, la estrategia escritural de la autora con las teorías de género contemporáneas. La búsqueda de dicha lectura se centra en trazar puntos de relación entre el texto de Yourcenar y los discursos teóricos actuales asociados a la construcción de las identidades masculinas. Esto con el propósito de resemantizar, desde la Literatura, conceptos y términos vinculados con la temática de género, ampliamente discutidos en otros campos de estudio.

Indudablemente, el desempolvar un texto de hace ochenta y cuatro años se convierte en un ejercicio que enriquece la labor historiográfica y los estudios literarios asociados a las teorías de género, puesto que Yourcenar, a través de su escritura, impugna el aparato punitivo y crea un topos textual que persigue romper con el silencio que teje las voces marginales.
\end{abstract}

Palabras clave: masculinidades, identidades, Literatura francesa, Yourcenar

\begin{abstract}
This article is an approximation to the french writer Marguerite Yourcenar's novel titled Alexis or the Treaty of vain combat (1929). This space provides a dialogue between the literary proposal of the text and the writing strategy chosen by the author with the contemporary gender theories. The search of the reading focuses on plot connection points between the text of Yourcenar and the current theoretical masculine identities constructions. All this with the purpose of resemanticize, from the literature, concepts and terms related to the theme of gender, widely discussed in other fields of study.

Undoubtedly, dusting a text of eighty- four years ago becomes an exercise that enriches the historiographic work and the literary studies about gender theories, since Yourcenar, through her writing, challenged the punitive device and creates a textual 'topos' that aims to break the silence that covers the marginal voices.
\end{abstract}

Key Words: identity, masculinity, French Literature, Yourcenar.

* $\quad$ Universidad de Costa Rica.

** Traducción: Geannette Soto. Escuela de Lenguas Modernas, Universidad de Costa Rica.

Correo electrónico: caroco_82@yahoo.com

Recepción: 22/04/13. Aceptación: 07/05/13. 


\section{A modo de introducción}

Una obra de arte nunca es lo suficientemente pobre como para no decirnos nada. Algunas de ellas desentierran historias, perpetúan pensamientos, exponen fantasías y ventilan emociones. Todas son diferentes; pero, a la vez, tan iguales: todas son expresión. Así, todos los textos literarios nos hablan a nosotros mismos y de nosotros mismos. En sus líneas se teje la ficción / realidad de la condición humana.

En esta oportunidad, nos aproximaremos a la novela de Marguerite Yourcenar Alexis o El tratado del inútil combate, cuya lectura sugiere la necesidad de realizar un acercamiento desde la noción de género.

La principal motivación para trabajar el texto desde esta perspectiva emergió a raíz del prólogo que Marguerite Yourcenar le incorporó a su novela en el año 1963. Éste, como todo paratexto, ofrece visos que, de una u otra manera, guían o anticipan nuestra lectura. La autora señala allí que después de varios años de la publicación de su texto, vuelve sobre él y al hacerlo es invadida por la idea de modificar su novela, sin embargo, admite que eso significaría escribir otro texto, y abandona esa tentativa. Aduce que no existe motivo alguno para alterar la novela puesto que la obra no ha envejecido; todo lo contrario, posee vigencia. Es decir, la historia de Alexis, en cierto nivel, podría ser hoy la de muchos.

Siendo así, resulta interesante revisar el planteamiento de Yourcenar y establecer una dialéctica con las propuestas más recientes acerca de la construcción de las masculinidades, pues pese a que la Literatura no retrata la realidad ni escribe la historia directamente, ningún texto se engendra de manera aislada, puesto que se circunscribe al orden social de su momento histórico. Retomar un texto de 1929 nos permite releer el pasado y resemantizarlo en el presente. Asimismo, permite revisar cómo han sido configuradas las identidades tanto femeninas como masculinas y cuáles de esos discursos nos mantienen atados en la época contemporánea.
Para ello se realizará la lectura de la novela Alexis o El tratado del inútil combate (1929) desde una perspectiva de género, lo cual permitirá mostrar mediante un análisis crítico cómo la obra de Marguerite Yourcenar esboza de manera sutil lo que hoy denominamos la crisis de la masculinidad y de qué modo el texto le permite a Alexis deconstruir el modelo de masculinidad impuesto socialmente.

Cabe advertir que el abordaje de un texto literario a partir de esta perspectiva plantea desde el inicio un reto y es, precisamente, la conformación de las identidades a partir de las nociones de género impuestas socialmente.

Al respecto, tanto las críticas como las escritoras feministas han elaborado teorías vinculadas con la reconstrucción de la identidad de la mujer anulada por la historia y oculta tras los modelos patriarcales. Dichas propuestas del movimiento feminista traen consigo no sólo el cuestionamiento, sino también el debilitamiento del sistema falocéntrico. En realidad, los planteamientos de estas mujeres en algunos casos acertados, en otros, confusos o contradictorios, le demostraron al mundo los puntos débiles de un sistema, hasta ese momento, estático.

Así, tras múltiples resistencias y debates la mujer se percató de que la ideología patriarcal la condenaba a un papel donde el protagonismo era nulo y donde sólo alcanzaría la trascendencia al escapar del eterno femenino que la reducía a objeto.

De manera similar, pero más lento, los hombres descubren también que la ideología patriarcal, en afán de mantener la cohesión social y el poder en manos del varón, implanta un único modelo. Este ideal masculino supone la superioridad con respecto a la feminidad, de allí, la existencia de una sola forma de lo masculino, donde quien no se amolda a ello es marginado (a) y enfrenta una crisis. Es decir, no existe espacio para pensar a los hombres desde las masculinidades.

\section{La posición de la crítica con respecto a la obra de Marguerite Yourcenar}

Ahora bien, en cuanto al texto de Marguerite Yourcenar, la crítica omite toda 
posibilidad de lectura desde las teorías de género, no existe un espacio para discutir acerca de la crisis de masculinidad sufrida por el personaje. No se menciona, en absoluto, el motivo principal del texto: escribir una carta para confesar la homosexualidad. Se prescinde de este aspecto y se centra en un punto insostenible: la negativa que halló Alexis en su familia para su realización como artista (pianista). Resulta lamentable que la crítica haya reducido esta obra a un único elemento. Quizás el motivo de ello es la ceguera y el miedo a la verdad.

Así lo confirman la mayor parte de las fuentes consultadas, las cuales remiten a la biografía de la autora. Mencionan que Yourcenar fue la primera mujer en ingresar a la Academia Francesa de la Lengua y se resalta el hecho de que ella junto a Grace Frick (mujer con quien convivió gran parte de su vida) reunió algunas de las cartas dirigidas a sus amigos. Esta correspondencia se mantuvo sellada en la Universidad de Harvard, durante medio siglo después de su muerte, en 1987; hasta que su primera biógrafa, Josayne Savigneau, publica Marguerite Yourcenar. L' invention d' une vie (1990) y da cuenta de éstas.

En síntesis, es notoria la predilección por los aspectos biográficos en detrimento del análisis de su obra. A excepción del estudio realizado por Jean Blot titulado Marguerite Yourcenar (1980), donde persiste la preocupación por señalar el interés por el mundo clásico, el mito y los arquetipos. Blot exalta el grado de intuición de esta escritora, la recurrencia a las imágenes para producir sensaciones en el lector, el intento de penetrar al interior del personaje y revelar la moral y la conciencia.

Dicho autor se refiere a la influencia recibida de Gide y de Píndaro. Blot afirma, en varias oportunidades, que Marguerite Yourcenar siente nostalgia por el pasado grecolatino, pues admira la libertad de los cuerpos, al goce del erotismo y la búsqueda de la belleza; y la escritura es la única que le permite acercarse a ello.

Jean Blot insiste en que esta autora procura hacer del pasado el eterno presente, ya que su época le niega lo que el ayer le ofrecía:
Le moment Pindare de l'histoire et de la sensibilité est celui oú la división sexuelle ne s'impose pas dans toute sa rigueur. Dans l'ombre qui précède l'aurore, règne une androgynie qui autorise et rend charmante la confusión oú, tout á l'heure, dans le midi du XX siècle occidental, il faudra reconnaître l'un des hauts lieux de la culpabilité (Blot 1980:52).

De este modo, el autor justifica el retorno de Marguerite Yourcenar al mundo clásico, en la medida en que éste se convierte en un ideal por seguir, un legado irrenunciable y uno modo de vida que se debería readecuar a su presente histórico.

Posteriormente, Jean Blot realiza un recorrido por las distintas obras literarias de esta autora y con respecto a Alexis o El tratado del inútil combate sostiene que este personaje se encuentra en medio del 'deber ser' y sus propias inclinaciones. En principio la posición de Alexis es: 'L'homosexuel préfère être la 'victime' $d$ ' une nature plutôt que celle d' un milieu ou d' une éducation. On serait homosexuel par substance et non par accident" (Blot 1980: 102).

Socialmente, Alexis debería asumir la aristocracia como la única forma de ser hombre, no obstante él elige enfrentar su realidad. Es justamente esta perspectiva diferente la que nos acerca al trabajo literario de Marguerite Yourcenar y nos aleja de lo meramente biográfico.

\section{Preludio textual}

El problema de la libertad sensual, en todas sus formas, es, en gran parte, un problema de libertad de expresión (Yourcenar, 2000: 15).

La novela de Marguerite Yourcenar posee como elemento paratextual un prólogo de 1963, el cual es el contrapunto de la lectura por realizar. La autora brinda en éste una serie de aspectos claves vinculados con la forma, el contenido, los personajes, el contexto, así como cuestionamientos en relación con la obra. Uno de los aspectos tratados ampliamente es la forma de expresión o escritura, ítem en el cual conviene detenerse, pues es elemental para realizar la lectura. 
Como bien señala Yourcernar en el epígrafe de este apartado, la problemática al hablar de sexualidad reside en la expresión. Ciertamente, a nuestra autora le preocupa el modo de escritura, es decir, qué estrategia debía emplear para escribir acerca de la homosexualidad y de qué manera podía Alexis realizar su confesión.

Por esta razón, Marguerite Yourcenar indica en el prólogo que quien decida narrar la historia de Alexis sólo podrá escoger entre tres procedimientos de expresión. El primero de ellos es el lenguaje científico, el cual es descartado, porque con el pasar del tiempo pierde exactitud $\mathrm{y}$, además, emplea etiquetas que funcionan solamente para obras especializadas. La segunda es la obscenidad, método literario que - según la autora- podría generar una respuesta dentro del público mojigato, sin embargo, su empleo, eventualmente, traería como consecuencia el efecto inverso: que el lector se acostumbre a ese lenguaje y, por ende, no consiga reacción alguna. Lo anterior, obliga al escritor a utilizar un tono cada vez más grotesco, alejado de la expresión sensata de la situación de personaje.

En última instancia, a Marguerite Yourcenar sólo le resta emplear una lengua que ella denomina escueta, la cual sirvió en Francia durante siglos a los predicadores, moralistas y a los novelistas de la época clásica para tratar lo que entonces llamaban "desvío de los sentidos". Ella volvió al estilo tradicional del examen de conciencia, narrado en primera persona.

\footnotetext{
Por su misma discreción, ese lenguaje decantada me ha parecido convenir a la lentitud pensativa y escrupulosa de Alexis, a su esfuerzo paciente por liberarse eslabón tras eslabón de una cadena que él desata más que rompe, formada por la red de incertidumbre y coacciones en las que se encuentra metido; a su pudor, en el que hay respeto a la sensibilidad; a su firme propósito a conciliar sin bajezas el espíritu y la carne (Yourcenar, 2000: 18).
}

Siendo así, podemos conectar la producción literaria de Andre Gide ${ }^{1}$ con el retorno a la forma clásica del relato en Marguerite Yourcenar. De hecho, en el prólogo la autora reconoce hasta cierto punto la influencia de éste.
Al respecto, conviene traer a colación el estudio de Ralph Freedman (1972) sobre André Gide, donde afirma que este autor francés trabaja a partir de la autocompasión irónica y la inclinación obsesiva hacia la autoexploración. Esta tendencia permea directamente el estilo de Gide, quien procura hacer el universo sensible para sus lectores, de allí el motivo de la recurrencia a imágenes que luego se transforman en percepciones personales.

En realidad, toda la obra gideana está orientada a mantener una relación entre la conciencia y las sensaciones, en busca de una trascendencia espiritual-estética del yo. Sus obras son relatos de emociones cuyas percepciones se filtran mediante la palabra, hasta conducir a sus lectores hacia la vida interior de los personajes; aunque persiste la objetivación del yo a través de la personificación neutra, la recurrencia a la primera persona e, incluso la confesión y la novela epistolar.

Dentro de su trabajo literario, Gide procuró evadirse en la impersonalidad y, por ello, -sostiene Freedman- presenta a un héroe disfrazado del yo, es decir, una ficción del yo. Dichas estrategias literarias hacen que el texto, según Ralph Freedman, "se convierta en el 'escenario interno' en el que la crisis de conciencia puede ser representada por varias figuras que reflejan el punto de vista del poeta" (Freedman, 1972: 206). Así, la conformación del 'escenario interior' obedece a la yuxtaposición de monólogos o confesiones donde el personaje, a través de imágenes y sensaciones, se revela ante el lector, quien se encargará de organizar a partir de ellas la red textual.

No se debe perder de vista que estos modos de escritura son el resultado del conflicto entre la auto-expresión y la sumisión del control exterior, hecho que intensifica la transformación del conocimiento sensible en conocimiento moral.

Por otra parte, los comienzos de Gide se ubican en el neo-romanticismo y en el simbolismo, pero su posición ambivalente lo conduce a establecer las posibles vinculaciones entre la conciencia y la forma, lo cual permite la auto-liberación y 
el rompimiento con las imposiciones de las instituciones sociales y morales.

De acuerdo con lo anterior, la mención de Gide en el prólogo de la novela de Marguerite Yourcenar no es inocente. Es posible establecer ciertas filiaciones vinculadas con la producción de imágenes y percepciones, donde será el lector quien estará encargado de interpretarlas. Se prefiere no enunciar el tema de la homosexualidad; primero, porque está tabuizado, es decir, los temas de sexualidad son encubiertos por un velo, predomina el miedo a decirse en ella; y segundo, al descubrir las sensaciones, el lector adquiere un mayor acercamiento a la realidad del personaje.

Sumado a lo anterior, la elección del género epistolar y la narración en primera persona le permiten a la autora distanciarse de su producción, en la medida que quien lea su texto, lee la confesión de Alexis. Esto podría concebirse como un recurso de verosimilitud, lo cual salvaguarda las eventuales acusaciones que podrían realizarse contra la autora, en caso de que la recepción del texto insinuará que es Marguerite Yourcenar quien confiesa su homosexualidad.

Cabe agregar que en el texto de Marguerite, Alexis encarna la representación de un personaje movido por la lucha interna, el miedo y la culpa. Es un hombre que se busca a sí mismo porque se resiste a aceptarse.

Siendo así, la huella de Gide en tanto retorno al clasicismo y al cuestionamiento moral atravesarán el texto de Yourcenar de manera irreductible. De esta forma, tanto la autoliberación, el rompimiento con las imposiciones sociales y morales como la búsqueda de las identidades conformarán los resabios de una propuesta planteada por autores como Proust, Wilde y Gide, en algún momento.

Por lo tanto, al leer esta novela no podemos obviar la intertextualidad de la propuesta literaria de Proust y de Wilde, ya que sus obras representan la apertura de un espacio para la marginalidad. Por supuesto, la visión y el tratamiento del tema de la homosexualidad no es estático, continuamente es evaluado y resemantizado.
Así, los planteamientos de un autor no son los de otro, las perspectivas varían y surgen otras nuevas, a partir de la conformación entre ellas. Un texto se genera a partir de muchos otros discursos que lo anteceden o preludian, por eso, es erróneo sostener que una producción literaria se engendra de la nada, el surgimiento de ésta se encuentra emparentado con otras propuestas estético-ideológicas.

Por ejemplo, encontramos a Proust quien con su obra Sodoma y Gomorra (1922) define al homosexual como "un ser invertido interior", es decir, es una mujer en un cuerpo de hombre. Desde esta noción, los homosexuales son dos mujeres que se encuentran, mas, no son realmente mujeres, sino seres hermafroditas quienes poseen los órganos de los dos sexos, como en los tiempos iniciales, antes de la división general de todos los seres. Además, sostiene que los homosexuales son una "raza maldita" porque cargan en sus hombros el peso de la injuria y el rechazo social.

Es evidente, entonces, que la reflexión de Proust acerca de la homosexualidad está fuertemente marcada por las representaciones homófobas y heterocentristas. Por este motivo, probablemente durante largo tiempo recibió no sólo apoyo, sino también la felicitación de la crítica por mostrar una actitud moralista ante "la abyección de una especie infame".

Por su parte, Oscar Wilde intentó concederle a los amores del mismo sexo un derecho de acceso a la expresión pública, de allí su esfuerzo por inventar gestos de resistencia y de separación de la norma.

De algún modo, Wilde intentaba forjar, a través de su literatura, un personaje o un rol desde donde fuera posible crearse así mismo al margen de las normas dominantes. Dentro de esta propuesta cobraba relevancia el hedonismo, dado que las relaciones de amistad servían para recrear una nueva subjetividad.

En sí, la producción literaria de Wilde, "consistió en abrir espacios de resistencia a la sujeción (el sujeto en cuanto sometido a un orden sexual que le [sic] interioriza) y en imaginar posibilidades de reinvención (...) como sujeto 
autónomo, construido contra, o al margen, de la norma heterosexual" (Eribon 2001: 341).

En realidad, el compromiso adquirido y la lucha a favor del grupo homosexual le generaron a Wilde grandes problemas y, finalmente, luego de un largo proceso judicial, fue condenado por un tribunal. Recibió sentencia porque la homosexualidad sólo podía practicarse de manera discreta y, como él no calló ni obedeció esta imposición, fue castigado. Este hecho evidencia cómo la represión de la homosexualidad ha alimentado históricamente la determinación de expresarla y de qué modo los sujetos han sido producidos por el orden social.

Tal y como se ha evidenciado no podemos escapar a las redes intertextuales presentes en Alexis o El tratado del inútil combate, pues en esta novela se traslapan inquietudes e impugnaciones presentes en otros autores. En cierto sentido, el texto literario se convierte, entonces, en un sitio de reconstrucción y de diálogo. Así, la búsqueda de una propuesta estética-literaria para anunciar lo indecible y el anhelo de alcanzar un espacio para el reconocimiento social de los homosexuales son, consecuentemente, ejes postulados por otros autores que se desplegarán dentro de la historia de Alexis.

Por ejemplo, en la obra de Marguerite Yourcenar se mantiene aún solapada la temática homosexual, sin embargo, la autora postula para ésta una causa biológica y no un motivo meramente social vinculado con el vicio o la corrupción de costumbres. En otras palabras, se produce un distanciamiento con la propuesta homofóbica de Proust. De allí, la riqueza que se desprende del retorno a textos anteriores a los estudiados y su evaluación.

\section{Alexis y la crisis de la masculinidad}

\subsection{La homosexualidad ${ }^{2}$ : lo indecible}

La primera consecuencia de las inclinaciones prohibidas es la de encerrarnos dentro de nosotros mismos: hay que callar (Yourcenar, 2000: 79).

Al acercarnos al texto de Marguerite Yourcenar comprobamos desde la primera página que se trata de una carta escrita por Alexis dirigida a su esposa, Mónica, con motivo de explicar (se) y confesar (se) el porqué de su partida. De antemano advierte que ese ejercicio epistolar no va a ser nada fácil "Si es difícil vivir, es aún mucho más penoso explicar nuestra vida" (Yourcenar 2000: 26). Y es que no sabemos si ciento sesenta y cinco páginas le resultaron suficientes a Alexis para enfrentar su realidad.

De cierta manera, todos los lectores de Alexis o El tratado del inútil combate nos convertimos, al igual que Mónica, en destinatarios de su carta. Desconocemos, en principio, cuáles son las razones que lo incentivan a escribir y qué tiene que decirnos; mas, poco a poco, el personaje se va desnudando ante nosotros, sin que nos percatemos. Alexis se va descubriendo a sí mismo y, simultáneamente, como lectores lo descubrimos a él.

Desde un inicio cala en nosotros la sospecha de que todo lo dicho y lo no-dicho por el personaje tiende a revelar lo escondido y lo íntimo de su ser. En cierto modo, sentimos como si estuviéramos violando la correspondencia privada o como si Alexis estuviera en el diván y nosotros fuéramos su psicoanalista ${ }^{3}$.

En sí, el texto conduce a los sueños, las agonías y las experiencias de su personaje. Alexis intenta reparar la mentira y la infelicidad, procura lavar una culpa, lucha contra sí mismo, sin percatarse de que él es el primer obstáculo.

$\mathrm{Su}$ extrema sensibilidad nos traslada a su infancia, a esa vida solitaria y monótona, a la cual le achaca la determinación del resto de su vida. La música parece ser para él la única alegría, es como si el arte le diera lo que nadie más podría darle: la libertad de expresarse, de ser él mismo.

De manera indirecta, Alexis elude página tras página el confesar esa verdad que lo atormenta. Por eso, intercala momentos de su vida con cuestionamientos metafísicos. Quienes leemos su carta podríamos pensar en algún instante que relata otros aspectos de su vida como el ambiente en Woroïno, el miedo al padre, la influencia de las mujeres en su vida, su visión del amor; todo eso, para no hablar de lo que 
interesa: su confesión. ¿O será acaso todo eso parte de su confesión?

En realidad, Alexis nunca confiesa nada explícitamente, somos nosotros como lectores quienes reconstruimos cada uno de los elementos que nos ha dado y al final, todo confluye en la reprimida e inconfesable homosexualidad. “Tu mérito amiga mía no está sólo en poder comprenderlo todo, sino en comprenderlo antes de habértelo dicho. Mónica ¿me entiendes? (Yourcenar 2000: 52).

La cita anterior nos muestra la reticencia y la negación de Alexis para confesar su realidad. No resulta fácil decirle a su esposa, con quien tuvo un hijo, que huyó de su lado porque se dio cuenta de que no podía continuar viviendo en una farsa. Alexis es consumido por la culpa, las luchas interiores que habitan en él lo aniquilan. Sin embargo, el papel y la pluma le conceden la posibilidad de expresarse, de descargar lo que lleva dentro. Su carta cumple una función catártica en la medida en que su ser se desdobla por completo, quien inicia esa carta no es el mismo que la acaba.

Ahora bien, resulta interesante preguntarse ¿por qué una carta? Bueno, podrían ser varias razones: primero, aunque Alexis está consciente de que las palabras lo traicionan, de alguna forma puede reescribir o tachar cualquier error, mientras tanto, en una conversación aunque rectifique, el error será conocido por el interlocutor; segundo, prefiere el género epistolar porque evita la presencia física de la persona a quien se la dirige; tercero, una carta le permite expresar hasta donde él quiera, puede reservarse muchos pensamientos sin que nadie lo interpele; y cuarto, desea que su confesión se conserve por mucho tiempo ${ }^{4}$. Las palabras dichas son evanescentes, mas las escritas permanecen con nosotros; es así como Alexis logra perpetuar su realidad a través de una carta que no sólo envía a su esposa, sino a una colectividad ${ }^{5}$. De hecho, él admite que pudo elegir otro modo de exteriorizar la verdad, empero no hubiera generado el mismo efecto. Alexis posee la certeza de que la superación de la culpa y la angustia de exteriorizar su homosexualidad significarán un reencuentro consigo mismo.

\begin{abstract}
Debería habértelo explicado en voz baja, muy lentamente, en la intimidad de una habitación, en esa hora sin luz en que se ve tan poco que casi nos atrevemos a confesarlo todo. (...) Hubieras querido ahorrarme lo que tiene de humillante una explicación tan larga; me hubieras interrumpido demasiado pronto y, a cada frase, yo hubiera tenido la debilidad de esperar que me interrumpieras (Yourcenar, 2000: 26).
\end{abstract}

Bien se podría sostener que Alexis escribe esta larga carta por él, no por Mónica. No se trata de cobardía, sino que está seguro de que se encontrará a sí mismo y resultará una revelación para él. Es un acto de purificación y ¿por qué no?, de expiación.

Es por esto quizás que a Alexis no le interesa narrar sus amoríos o aventuras, en principio, le parece censurable y además siente que eso le podría causar más daño a Mónica.

\footnotetext{
Hasta ahora no he dicho nada de los rostros en los que se encarnó mi deseo, no he interpuesto, entre tú y yo, más que fantasmas anónimos (...) No te asustes: no voy a describirte nada; no te diré los nombres; incluso he olvidado los nombres o no los he sabido nunca (Yourcenar, 2000: 93-94).
}

De ello se deriva su preocupación por argumentar o darnos las razones de cómo su vida difiere de lo socialmente establecido. Alexis aunque no lo diga, nos grita calladamente ¡Soy distinto, no soy como todos! Es en realidad un grito que se ahoga en el tiempo porque persiste el miedo a la moral, la religión y la familia, "se visualiza, de este modo, la opresión cultural realizada por el patriarcado sobre el varón (Cortazzo, 2002: 3). Esas autoridades que le dictan cómo debe ser le impiden decir y gritar lo que es: "Cada palabra que escribo me aleja un poco más de lo que yo quisiera expresar; esto prueba únicamente que me falta valor (Yourcenar, 2000: 27).

¿Valor para qué? Acaso para nombrar lo indecible, para decir "soy homosexual", tal vez antes de hacerlo Alexis hubiera preferido negarlo rotundamente. En efecto, quizás la crisis que sufre este personaje se debe justamente a la afirmación que postula la homosexualidad como lo indecible, es decir, Alexis se siente ajeno a una sociedad que reniega lo que él es. Debe callar, aparentar, jugar a dos caras: 
Así pues, el control de la homosexualidad descansa en ese silencio impuesto y en esa disimulación forzosa, y sobre todo en ese sentimiento de culpabilidad e inferioridad que no se puede por menos de producir la inscripción en las conciencias individuales de la escisión entre lo que uno es y lo que puede hacer, entre lo que es y lo que puede decir (Eribon, 2001: 79).

Mas, Alexis decide finalizar esa situación, no soporta más el silencio y la mentira; es entonces cuando se quita la máscara y escribe. A través de la escritura y la música, Alexis expresa quien es en verdad. Ya nos lo decía Marguerite Yourcenar en el paratexto "El problema de la libertad sensual es más un problema de libertad de expresión". Sin duda alguna esto es así, pues jamás lograríamos la aceptación social de la homosexualidad cuando está vedado hablar de ella. Además, no olvidemos que los significantes se incorporan a la realidad en el momento en el cual se les nombra. Es decir, la inexistencia social de la masculinidad de Alexis terminará en el instante en el que decide nombrarse y permite que nosotros lo podamos nombrar.

Asociado a este último aspecto, la postura de Didier Eribon (2002) conduce a cuestionar que el afirmarse como gay no debe homologarse con la aceptación; no obstante representa el primer paso para el reconocimiento social.

(...) lo que genera el problema no es tanto ser homosexual como decirlo... Pues si la posibilidad de decirlo se admitiera oficialmente, quedarían anuladas por completo la inferioridad y la vulnerabilidad de los gays y las lesbianas, así como los medios de control que pueden ejercer sobre ellos (Eribon, 2001: 79).

Lo anterior cuestiona si realmente se puede hablar de libertad, pues un hombre no tiene elección para desarrollar su masculinidad, sólo existe un modelo y, cuando no encaja en éste, será castrado. Mas, la lectura de Alexis $o$ El tratado del inútil combate nos muestra que no todo está dicho, ya que en el instante en el que un hombre decide renunciar al silencio y comienza a hablar de sí mismo, 'el sacralizado macho' y la tendencia heterosexual del sistema patriarcal parecen perder fuerza y comienzan a desvanecerse para cederle espacio a las voces acalladas.

\subsection{Un cristal con muchas aristas}

En este apartado Alexis será como una figura de cristal que puede ser observada desde diversos ángulos; esto no resulta antojadizo, dado que el texto de Yourcenar así lo exige. Indudablemente, la imagen de Alexis se va delineando entre la culpa, la angustia, la moral y la religión. Por este motivo, es necesario ir uniendo los vértices de esas aristas para completar una efigie que luego él mismo se encargará de destruir.

Las verdades que Alexis revela en su carta no surgen espontáneamente, se resisten a salir, él mismo se encarga de retenerlas. Predomina la censura y el tabú, hay un rechazo rotundo hacia aquello que se aparta de lo establecido. Esa negación se origina en su interior y trasciende a una sociedad que aísla a quienes no se someten a sus mandatos.

Alexis no se acepta a sí mismo, siente repulsión e intenta combatir un aspecto que le es inherente. "No tenía nada que hacer: iba y venía, cansado de ver mi imagen reflejada en el espejo; odiaba a aquel espejo que me infligía mi propia presencia" (Yourcenar, 2000: 102).

Este sentimiento se evidencia claramente en su propia concepción de la homosexualidad, ya que inicialmente la percibe como una enfermedad, hecho que lo condena a la soledad y al sufrimiento. "Sé que hay nombres para todas las enfermedades y aquello de lo que quiero hablarte pasa por ser una enfermedad" (Yourcenar, 2000: 44).

Alexis insiste en otorgarle a su homosexualidad cualquier otra justificación: pecado, vicio o accidente, jamás su propia definición de masculinidad.

El vicio consistía para mí en la costumbre del pecado (...) Al explicar mi culpa como un efecto de las circunstancias, a las que yo me proponía no exponerme nunca más, las separaba de mí para no ver en ellas más que un accidente. (Yourcenar, 2000: 77). 
El anteponer diversas causas a su realidad constituye, sin duda, un acto de evasión. Alexis desea distanciarse sus inclinaciones para no enfrentarlas; se muestra indiferente ante ellas al atribuirles justificaciones alejadas de su propia voluntad. Y es justamente ese rechazo hacia sí mismo la causa de las luchas internas que acaban por impugnarle el deseo de muerte como única solución. En múltiples ocasiones llega a reprimirse, mas es allí donde la prohibición se convierte en condición de un deseo. Alexis se encuentra en medio de las representaciones e identidades fabricadas por la historia preexistente a todos los individuos. "No creamos el mundo al que llegamos, sino que en él encontramos gestos, roles sociales, creencias, oficios, hábitos mentales, etc., que nos han precedido" (Eribon, 2001: 91).

Sumado a lo anterior, se anteponen las ideas con las cuales había sido educado, parecía que le resultaba imposible poder salir de ellas, era como si desde su nacimiento estuviera condenado a estar atrapado en una concepción masculina predeterminada.

\begin{abstract}
Había tenido, en mi familia, admirables ejemplos de ternura femenina; mis ideas religiosas me llevaban a ver, en el matrimonio, el único ideal inocente y permitido. Imaginaba que una joven muy dulce, muy afectuosa y muy grave terminaría algún día por enseñarme a amarla (Yourcenar, 2000: 131).
\end{abstract}

Alexis estaba consciente de que no podía llenar esas expectativas, no obstante, todo su dilema lo vivía en silencio; se guardaba sus emociones, no se atrevía a decir nada y - mucho menos- se atrevía a colocarse en contra de ellas. En realidad, el seguimiento de la moral lo atormentaba en cada una de sus acciones, se obsesionaba con la búsqueda de una conducta perfecta, pero esto sólo representa su oposición a la diferencia presente en su propio ser.

\footnotetext{
La subjetividad de Alexis era producida por la interpretación de las estructuras sociales. "El orden social y sexual cuyo vehículo es el lenguaje, (...) produce al mismo tiempo el sujeto como subjetividad y como sujeción, es decir, como una persona adaptada a las reglas y a las jerarquías socialmente instruidas" (Eribon, 2001: 88).
}

Es así como los actos y los pensamientos de Alexis siempre están mediatizados por la culpa, infundada en los prejuicios sociales, las concepciones patriarcales de 'lo masculino' y sus verdaderas inclinaciones. Son, justamente, estas "falsas verdades" las que lo mantienen atado a un sitio donde no pertenece. La opinión de los demás y la demanda social cobran más peso que su propia libertad de ser: "Naturalmente, sólo podía juzgarse según las ideas admitidas a mi alrededor", "Es la opinión de los demás la que confiere a nuestros actos una especie de realidad" (Yourcenar, 2000: 73, 76).

De esta manera, el personaje se tambalea entre ser y no ser y, en medio de ese conflicto, surge la idea ingenua de "rectificar sus inclinaciones". Emprende actos ajenos a sus deseos, los realiza con el único objetivo de adaptarse a las solicitudes de las fuerzas coercitivas. La presión social se convierte en una carga que alterna con la culpa.

(...) la subjetividad de un homosexual se constituye
en un proceso de educación de sí mismo mediante la
severa autodisciplina que debe imponerse en cada
instante, en cada gesto "para parecer tan normal"
como los demás (...) Es la necesidad de "hacer
como si", un esfuerzo permanente para que no tras-
luzca nada de las propias emociones, sentimientos,
deseo (Eribon, 2001: 139).

En todo instante se intenta encubrir la personalidad y los deseos para cumplir con el canon establecido. "La masculinidad como condición social (deber ser) demostrada en contextos sociales específicos. Digo demostrada, porque la afirmación pública es absolutamente central en la condición masculina. Se actúa de cierta manera porque hay que probar que se es hombre" (Pérotin-Dumon 2001: 5)

Esta idea obsesiva genera una tensión intolerable, la cual repercute en la subjetividad del individuo. Es así, como Alexis llega a concebir en sus pensamientos la idea de que el matrimonio representaría una cura a su homosexualidad, es como si al lado de una mujer pudiera escapar de su propia realidad. "(...) el matrimonio de "conveniencia" ha sido para numerosos homosexuales el medio 
de eludir la sospecha y la "estigmatización" (Eribon 2001: 92).

Alexis consideró que al contraer nupcias con una mujer cumpliría -de una vez por todascon esa obligación social; mas su compromiso no finalizaba allí, el estar casado le exigía asimismo, procrear, ser padre, perpetuar su nombre, su sangre. Una vez que Alexis había engendrado una familia, se podía dar por cumplida su rol de hombre. Es como si tuviera que saldar una deuda que había contraído al nacer con pene; ley patriarcal a la cual todavía no se atrevía a desafiar.

Si consentías en casarte conmigo, a pesar de todo, era como echar una sombra sobre la confianza que tenías en mí. (...) Me creía con derecho (deber, más bien) a no rechazar la única tabla de salvación que la vida me ofrecía (Yourcenar, 2000: 132).

Así que la voluntad que expresaban las caras de mis antepasados habían terminado por realizarse; nuestro matrimonio había tenido una finalidad: nuestro hijo (...) Ya importaba poco que mi existencia continuara. Ya no les interesaba a los muertos y podía desaparecer, morir o bien empezar a vivir otra vez (Yourcenar, 2000: 155).

El odio hacia sí mismo y la homofobia interiorizada lo conducen a la obsesión de llevar una doble vida: establece una realidad hostil con las personas y borra quien es para pertenecer al orden heteronormativo. No obstante, muy pronto, su proyecto nupcial fracasa y también con ella la idea de 'ser hombre'. Alexis se da cuenta de que no es feliz y que, además, no ama a su esposa. Cuando nace su hijo, confirma que nada ha conseguido con ese matrimonio; él continúa siendo miserable y, peor aún, se culpa por haberle arruinado las ilusiones a una gran mujer.

De cierto modo, Alexis procuraba brindarle a Mónica algunas pistas que lo acercarán a la confesión. Y aunque ninguno de los dos dijera nada, ambos sabían que todo había terminado, la tristeza era lo único que los mantenía unidos. "Había tomado la costumbre de las semiconfidencias: te torturaba con confesiones, siempre inquietantes por no ser completas. Encontrábamos en las lágrimas una especie de satisfacción miserable: nuestro doble desamparo terminaba uniéndonos tanto como la felicidad" (Yourcenar, 2000: 143).

\subsection{Alexis: un cristal fragmentado}

Al principio creí que se trataba de evitar
las ocasiones de pecado;
pronto me di cuenta que (...)
es nuestra naturaleza lo que
habría que cambiar (Yourcenar, 2000: 100).

Verdaderamente, Alexis intentó encajar en un molde inventado e imaginado, pero no lo consiguió; su naturaleza se lo impidió. Y cuando se percata de ello, destruye esa idea de masculinidad de la cual nunca fue partícipe.

Es por este motivo que Alexis, aún en medio de las contradicciones en las cuales se hallaba envuelto esboza - sutilmente y de manera esparcida en el lienzo textual- las cualidades que lo hacen diferente del resto.

En primer lugar, Alexis nos remite a su niñez. Nos dice que durante esta etapa vivió con sus hermanas y su madre, por lo cual la influencia de éstas en su vida es muy marcada. Por ejemplo, la primera impresión del amor la obtuvo a través de las vivencias románticas de sus hermanas. En su hogar no se acostumbraba a hablar sobre los romances o placeres sexuales, en realidad, se prefería el silencio, nadie expresaba sus emociones tal vez por miedo, pudor o vergüenza.

Alexis fue educado entre mujeres y su padre murió cuando era niño. Hito que para muchos puede representar la única razón por la cual él optó por el 'modelo femenino', en lugar del que supuestamente le correspondía: 'el masculino'. Si bien, el influjo del entorno en donde se desenvolvió el personaje es relevante, éste no debe considerarse como el factor determinante de su homosexualidad. En otras palabras, Alexis no es homosexual únicamente porque durante su infancia careció del modelo paterno, sino porque ésa es su naturaleza y nada podía hacer su entorno para evitarlo, tan sólo motivar la represión. "Aunque esto no permita explicar la totalidad y la multiplicidad de las experiencias homosexuales, se sabe que innumerables relatos tienden a mostrar que la "orientación sexual", 
para gran número de gays y lesbianas, se remonta a la primera infancia" (Eribon, 2001: 137).

Esta opinión también la expresa Alexis en su carta. Él, pese al torbellino de reproches que lo invaden, logra esclarecer en su mente que sus inclinaciones pudieron fijarse por influencias exteriores; no obstante, asegura que las razones más fuertes son las que maneja interiormente. Es decir, se da cuenta de que no puede considerar a la homosexualidad como un vicio o una mala costumbre. Es otro modo de ser, otra forma de vivir y sobre esto, no se tiene dominio. "Únicamente quisiera demostrar que mis instintos justamente porque eran naturales en mí, podrían desarrollarse durante largo tiempo sin que yo me diera cuenta" (Yourcenar, 2000: 53).

Es decir, no se trata de un comportamiento o conducta aprendida que se puede transformar, es más profundo, es una determinación natural. Así por ejemplo, Alexis posee una gran sensibilidad independientemente de si el constructo social lo acepta o no. "Ya te lo dije que yo era un niño muy sensible a la belleza. Presentía ya que la belleza y los placeres que nos procura merecen toda clase de sacrificios e incluso de humillaciones" (Yourcenar, 2000: 47).

De manera similar, el hecho de que Alexis no sostuviera una relación con una jovencita generaba extrañeza e inclusive sospecha. Como se mencionó antes, nuestro personaje le concedía relevancia a esas opiniones, pero en su interior operaba la verdad: "No se siente pasión por lo que se presenta ni quizás por lo que se ama. Sobre todo, no se enamora uno de quien se le parece y yo no difería mucho de las mujeres" (Yourcenar, 2000: 52).

Según lo anterior, Alexis es consciente de que su manera de ser no corresponde al paradigma heterosexual: su sensibilidad, su gusto por la música y la identificación con lo 'femenino' son causas suficientes para ser marginado y censurado socialmente.

Ahora bien, cuando Alexis aborda este aspecto en su carta, ataca al sistema patriarcal y a quienes lo refuerzan. Es en este punto donde se evidencia con mayor efervescencia la crisis de la masculinidad; por ello, alude a la intolerancia, la homofobia de la sociedad y al hermetismo ideológico homologable con una ceguera que impide superar la idea unívoca de 'lo masculino'.

De acuerdo con su opinión, para la colectividad resulta más sencillo oponerse a la homosexualidad que aceptar la alteridad, pues ello implicaría abandonar la idea de que todos somos iguales. Esta situación provocaría el desenmascaramiento de los aparatos ideológicos, donde la humanidad descubriría que ha estado subordinada al pensamiento arbitrario y antojadizo de una minoría que ampara la existencia de dos modelos únicos: la feminidad y la masculinidad. Antes de dejar al descubierto que el mundo se mueve a partir de estas dos polaridades, es preferible prohibir cualquier tendencia que coaccione el 'orden' y la cohesión social.

Y a pesar de que Alexis conoce muy bien lo que esperan de él, no está dispuesto a continuar mintiendo, se rehúsa a tener que cumplir con el único modelo del escaparate: ser hombre.

La gente que habla de oídas se equivoca casi siempre, porque sólo ven lo de afuera y lo ven de una forma grosera. No se figuran que los actos que juzgan reprensibles puedan ser al mismo tiempo fáciles y espontáneos, como lo son la mayoría de los actos humanos. Echan la culpa a los malos ejemplos, al contagio moral y sólo retroceden ante la dificultad de explicarlos. No saben que la naturaleza es más diversa de lo que suponemos: no quieren saberlo porque les es más fácil indignarse que pensar. (Yourcenar, 2000: 53).

Veámoslo así, mientras Alexis procura ser comprendido por Mónica también apela al cuestionamiento del patriarcado. Con ello, no busca justificarse, sólo pretende abrirle los ojos a quienes lean su carta. No quiere ser juzgado desde fuera, desea que tomen en cuenta sus circunstancias. Sugiere empatía para acabar con cualquier crítica hecha a la ligera y demanda la apertura de las mentalidades con el propósito de aniquilar 'el ideal de hombre' y empezar a hablar de multiplicidad.

Con dichas afirmaciones Alexis hace notar que se encuentra en crisis la masculinidad que le han impuesto otros. Es ahí donde se rompe ese cristal de la culpa y la angustia. Todas las 
piezas están fragmentadas y será a partir de ellas que más adelante comenzará a reconstruir su propia masculinidad.

\section{Alexis y la deconstrucción de la masculinidad}

\subsection{Alexis frente al espejo ${ }^{6}$}

No son nuestros vicios lo que nos hacen sufrir, sólo sufrimos por no poder resignarnos a ellos (Yourcenar, 2000: 103).

Cuando nos miramos frente al espejo ¿qué percibimos? En primer lugar, un cuerpo sea femenino o masculino ¿pero, qué más proyecta? Pues, una historia, una vida y un pasado que nos atraviesa indudablemente. Frente a un espejo es posible el reconocimiento y el encuentro con nosotros mismos.

En el caso de Alexis, la experiencia especular representa un conflicto existencial, en la medida en que la figura reflejada en esa superficie le devuelve una imagen borrosa de sí. Él teme mirarse porque no le agrada lo que ve. Talvez quisiera observar otro cuerpo, pero eso resultaría inútil, podría tener otro rostro, ser distinto; mas eso sería sólo su apariencia porque interiormente seguiría siendo Alexis.

Verdaderamente, la solución a su crisis no se hallaba en la búsqueda externa de otro 'yo', sino más bien, en la reconciliación con el 'yo' interior. Alexis debía enfrentar el miedo a ser diferente, a ser él.

Era tiempo para dejar de huir de sí mismo, no había motivo para ello, si se aceptaba tal cual era, ya no tendría que sucumbir ante las enfermedades nerviosas padecidas desde la adolescencia. Tampoco habría de retirarse para evitar las tentaciones, no tendría que concentrarse en el estudio para no pensar y amortiguar los combates interiores. "Hasta ahora, sólo has visto de mí los temores, los remordimientos y los escrúpulos de conciencia, ni siquiera de la mía, sino de la de los demás que yo tomaba por guía" (Yourcenar, 2000: 163).

Para franquear esa crisis de la masculinidad es vital derrumbar los modelos impuestos por el patriarcado. "De lo que se trata, (...), no es que un hombre tenga relaciones sexuales con otro hombre, sino de que esa persona esté rompiendo con lo culturalmente establecido para su sexo" (Edith 2003:1).

Es decir, Alexis debe abandonar la obsesión de apegarse a un patrón que anula la diversidad de vivir la masculinidad. No puede continuar encarnando un ideal que escapa a su naturaleza. A esto Eribon agregaría que “(...) la vida de un individuo está obsesionada por las elecciones que no ha hecho" (Eribon 2001:59)

Por esto, no puede ni tiene el derecho de permanecer al lado de una mujer a quien no ama, sólo para conservar una apariencia insostenible. Tampoco merece privarse de su sexualidad ni esconder sus emociones porque otros así lo dictan. En realidad, el declararse homosexual implica necesariamente un "desaprendizaje" de todas las "apariencias" simuladas tanto tiempo. "Era el mismo que había sido, quizás de una forma aún más profunda ya que, a medida que van cayendo una tras otra nuestras ilusiones y nuestras creencias, conocemos mejor nuestro “yo" verdadero" (Yourcenar 2000: 156)

Alexis, tras intentar repetidamente disimular su "defecto", se encuentra desgastado por las mentiras y decide romper con el espejo ilusorio que le brindaba una imagen ajena y distorsionada de sí mismo. Para Eribon (2001) esto implicaría el aprendizaje de un nuevo lenguaje, una nueva manera de hablar y de concebirse a sí mismo, pues para él todo homosexual ha aprendido a mentir.

Por primera vez, Alexis deja de notar en el espejo el perfil que otros han formado de su persona; ahora es él quien se ve a sí mismo. Ya no observa a través de la mirada de otros, ahora, son sus ojos los que perfilan su vida en el cristal.

Nuestra vida. Una vida que sólo a nosotros nos parece, que no vivimos más que una vez y no estamos seguros de comprender del todo. (...) Los demás ven nuestra presencia, nuestros ademanes, nuestra manera de formar las palabras con los labios: sólo nosotros podemos ver nuestra vida (Yourcenar, 2000: 45).

Las palabras de Alexis son muestra de su autoreconocimiento, se percata de que la vida es 
solamente una y que al ser nuestra no podemos vivirla a través de otros. $\mathrm{Y}$ es que al final desconocemos si nosotros construimos nuestra vida o ella nos construye a nosotros.

Ahora bien, en este punto, todas sus tensiones lo conducen hacia la deconstrucción de un discurso interiorizado y le permiten construir su propia masculinidad sobre los añicos de un modelo ficticio. En palabras de Eribon sería "no aceptar ya que se confiera un sentido desde el exterior sino reasumirlo desde el interior" (2001: 154).

El primer eslabón que posibilita la ruptura con el sistema unívoco de lo masculino y que conlleva, a su vez, a un estadio próximo a la aceptación de la homosexualidad vendría a ser la determinación de la diferencia. Esta última viene a ser el distanciamiento de la construcción de la masculinidad a partir del elemento sexual, es decir, no todos los individuos por poseer pene tienen necesariamente que ser heterosexuales, agresivos, insensibles, proveedores, etc. Alexis encarna la comprobación de esto. Él es sensible, admira la belleza y le atraen los hombres: él no es como el resto. Y aunque al principio se avergüenza de su realidad, frente al espejo, no puede engañarse a sí mismo: "Terminaba por decirme que mi único error (mi única desgracia, más bien) era ser, no el peor de todos, sino únicamente diferente $^{7}$ (Yourcenar, 2000: 147-148).

Precisamente, la diferencia le permite a Alexis comenzar a construir 'su' masculinidad y olvidar 'la' masculinidad. Ésta vez nadie le dirá qué debe hacer y qué no, deberá ser él frente al espejo, frente al mundo.

Y el gesto deliberado y liberador por el cual, un buen día, se decide romper con la obligación del secreto, el acto por el que uno hace pública su homosexualidad, señala la negativa a someterse por más tiempo a la violencia (interiorizada) que ejerce la dicotomía intensamente vivida entre lo que puede decir en público y lo que debe quedar confinado a la vida privada o el fuero interno (Eribon, 2001: 146).

Sumado a lo anterior, Alexis descubre que su tendencia sexual y su modo de ser no son causados por factores externos a él: vicios inducidos, experiencias traumáticas en la infancia o un afán subversivo. Él es partidario de que la causa es fisiológica y no puede sentirse culpable porque la sociedad no acepta este argumento. Inclusive, a él le lleva tiempo asimilarlo. Descubre que aunque no pueda explicar el porqué de su situación, debe aprender a convivir con ello y tomarlo como parte de sí, de lo contrario, permanecerá encerrado en un mundo de culpa. "Es humillante pensar que tantas aspiraciones confusas, tantas emociones (sin contar los sufrimientos) tienen una explicación fisiológica. Al principio, esta idea me avergonzaba, pero luego terminó por tranquilizarme. También la vida no es más que un secreto fisiológico" (Yourcenar, 2000: 43).

Podríamos preguntar: ¿culpable de qué? ¿De ser diferente, de no seguir un patrón, de ser él mismo o de mostrar la vulnerabilidad del patriarcado? Realmente, no hay culpa, el ser humano no posee dominio sobre la naturaleza; tan solo, voluntad sobre los actos.

$Y$ en el caso de Alexis, para él la superación de la culpa supone el retorno a la niñez, a la vida con su madre, a los romances vividos, a todos los hechos que marcaron su vida; en dicha exploración subyace la resemantización del pasado y la comprensión de muchos aspectos recónditos de su vida. Estamos ante la posible reconstrucción de su masculinidad, donde se conjuga el presente y el pretérito en aras de la aceptación de sí mismo. "No me quedaba ya, después de haberme prohibido tantas cosas, el valor de prohibirme mi pasado" (Yourcenar, 2000: 104), "Creo que aquellos años de infancia han determinado mi vida" (Yourcenar, 2000: 38 ).

\subsection{Entre la aceptación y la trascendencia}

$$
\begin{array}{r}
\text { Lloré de que la vida fuera tan sencilla y tan fácil } \\
\text { si nosotros lo fuéramos lo bastante } \\
\text { para aceptarla tal como es } \\
\text { (Yourcenar,2000: 114). }
\end{array}
$$

Tal y como se ha evidenciado, el texto de Marguerite Yourcenar le permite al lector adentrarse en la conciencia del personaje, y es 
así como descubrimos que la vida de Alexis gira en torno a la música. Precisamente, su gran sensibilidad lo llevó a dedicarse a ella y desde los dieciséis años se convirtió en pianista, impartía clases particulares e incluso, llegó a ofrecer un concierto, sin embargo, no obtuvo gran éxito.

Las razones que justifican la predilección de Alexis por la música son bastante obvias. En primer lugar, este arte le brindaba la oportunidad de expresarse, era un escenario donde Alexis podía ser él, sin que nada más importara. Entonces, podríamos colegir que el piano se trocaba en espejo, pues era allí donde se desvestía por completo y era sincero consigo mismo: “(...) una música se elevaba dentro de mí. (...) Dejaba de ser el joven enfermizo y asustado de sí mismo y me convertía en lo que yo era de verdad, porque todos nos transformaríamos si nos atreviéramos a ser lo que somos" (Yourcenar, 2000: 64).

La interpretación musical le proporcionaba a Alexis la libertad absoluta, es el espacio donde consigue encontrarse a sí mismo. Quizás por esto, cuando toca el piano, los pesares se alivianan, no dominan su vida porque éstos se transforman o pierden fuerza por la acción de la música. Incluso se podría afirmar que existe cierta dependencia, pues él la define como un tranquilizante capaz de hacer más llevadera la angustia de su existencia. En estos términos, la música desencadena una liberación donde se crean otros mundos alejados de la cruda realidad:

Durante toda mi vida, la música y la soledad ha representado para mí el papel de calmantes. (Yourcenar 2000: 65). La música me transporta a un mundo en donde el dolor sigue existiendo, pero se ensancha, se serena, se hace a la vez más quieto y más profundo, como un torrente que se transforma en lago (Yourcenar, 2000: 108).

Asimismo, este arte representaría para Alexis complicidad, ya que él deposita en la música toda su agonía, le habla sin pronunciar palabra; hay una conexión más intensa que supera todo lenguaje. Y es que podemos detectar un aspecto común entre la música y Alexis: ambos se conforman de silencios.

Toda melodía está construida por notas y silencios, gracias a esto se produce la armonía musical. De manera similar, en la vida de Alexis encontramos una serie de hechos y silencios que se entretejen. $\mathrm{Y}$ en ambos casos, resultaría iluso dudar de que los silencios sean también significantes en espera de ser descifrados de múltiples formas. "Siempre me ha parecido que la música debería ser silencio, el misterio de un gran silencio que buscara su expresión" (Yourcenar, 2000: 109).

Así, el silencio es expresión de lo no-dicho o de lo in-decible. El silencio opera cuando el lenguaje se ha agotado, cuando no se cuenta con interlocutores que compartan el discurso. En el ruido no percibimos el silencio, no es posible escucharnos a nosotros mismos. De algún modo, Alexis encuentra en la música un cómplice; este hecho es trascendental, pues de no ser así, resultaría impensable la confesión, es decir, el texto literario.

La noche anterior a la partida de Woroïno y luego, del nacimiento de su hijo Daniel, Alexis decide tocar el piano al que había renunciado tiempo atrás. En ese instante, descarga el dolor que lleva dentro de sí; esperaba que la música se llevara consigo ese pesar.

Alexis entra en un estado de decaimiento, está agotado de luchar, no puede continuar. De repente, descubre que había cometido un gran error al vivir durante tanto tiempo en silencio, él siente repudio por la farsa y la mentira vividas. Es pertinente, mencionar que “(...) la opresión es mucho más intensa sobre lo invisible y lo secreto, en la medida en que la interiorización de la dominación en el ánimo del dominado es lo que garantiza su sumisión al orden social y a sus jerarquías" (Eribon, 2001: 97). "Pequé del silencio ante ti y ante mí. Cuando el silencio se instala dentro de una casa, es muy difícil hacerlo salir; cuanto más importante es una cosa, más parece que queramos callarla" (Yourcenar, 2000: 38).

Tras la exaltación que Alexis vive esa noche, llega a descubrir sus dos manos sobre las teclas del piano, manos que asumirían la liberación mediante la escritura. Es por medio de esta metonimia que se rompe el silencio y la página en blanco se inunda de una voz que se había condenado a callar. Alexis comienza a ser él, desde la palabra, desde el texto. Por ello, 
le escribe la carta a Mónica donde le confiesa la verdad. Al escribir, Alexis busca perdonarse primero a sí mismo y, luego, solicitarle el perdón a su esposa: “(...) te pido perdón, lo más humildemente posible, no por dejarte, sino por haberme quedado tanto tiempo" (Yourcenar, 2000: 164).

Con esta última frase Alexis le dice adiós a Mónica y a toda su vida marcada por la falsedad. Ya no estará a merced de lo que otros le digan, él será quien hable de ahora en adelante. Y aunque admite que quizás la aceptación no le brindará la felicidad, sabe que conocerá la tranquilidad y eso le basta: "La vida me ha hecho lo que soy, prisionero (si se quiere) de instintos que yo no he escogido pero a los que me resigno, y esta aceptación, espero, a falta de felicidad, me procurará la serenidad" (Yourcenar, 2000: 164)

$\mathrm{Y}$ es justamente esta disposición del personaje lo que da pie para pensar en una posible aceptación de su homosexualidad y quizás la trascendencia, entendiendo ésta como la superación de la masculinidad.

La novela de Marguerite Yourcenar va más allá de una confesión, puesto que Alexis no sólo decide no callar más, sino que al negar la masculinidad impuesta desde su sexo, la supera y aniquila la tendencia a la igualdad cuando impera la diferencia.

Así, cuando el texto le voltea la espalda al patriarcado, plantea la noción de conformar masculinidades capaces de responder a las necesidades del individuo y a su propia experiencia. "No sabiendo vivir según la moral ordinaria, trato, por lo menos, de estar de acuerdo con la mía" (Yourcenar, 2000: 165)

En este sentido, habría un espacio para la libertad y la expresión, donde la posibilidad de ser, no sería una, sino plural. Sin embargo, lamentablemente, este grado de apertura y trascendencia, planteado en un texto de 1929, no abarca ochenta y cuatro años después el resto de la sociedad; esto evidencia que la visibilidad no anula la opresión, mas constituye para el sujeto, que decide no continuar ocultándose, el comienzo de un proceso interminable: la búsqueda de la identidad propia.

\subsection{Una identidad por construirse}

\author{
La masculinidad es un modo de ser \\ cuya definición constante \\ acompaña la evolución humana \\ AnnePérotin-Dumon
}

Según los apartados 2.1. y 2.2. el homosexual debe encarnar durante mucho tiempo lo que no es y llevar una vida disociada, pero llega un momento donde debe elegirse a sí mismo y romper con las determinaciones patriarcales.

Por ello, Alexis al confesar su homosexualidad, relativiza el concepto de virilidad, desgarra la creación simbólica que el patriarcado había determinado para él. Y es justamente allí, donde Alexis acaba con la crisis de la masculinidad porque decide desatarse de los patrones heteronormativos, ya no va a estar supeditado al modelo que ya ha rechazado y deconstruido. El sistema patriarcal se resquebraja cuando las cualidades que sustentan 'la' masculinidad resultan insostenibles e irrealizables en Alexis.

Este hecho es crucial, en tanto, logra revertir y fragmentar el modelo; mas acarrea otras implicaciones, como dejar atrás la sumisión de la cultura patriarcal para apropiarse - en palabras de Uruguay Cortazzo - de una cultura masculina donde la homosexualidad será una opción más de vivir la masculinidad.

La diversidad de apariencias no solo relativiza el concepto de virilidad (...) [sino que también] demuestra la existencia de una polémica en torno a una imagen mayoritaria que se quiso presentar como la única alternativa posible (Cortazzo, 2002: 3).

Es así como la novela de Marguerite Yourcenar sugiere el desplazamiento de los límites impuestos, ya que apela a la transformación del sistema mediante la pluralidad. Por ello, tal y como lo expone Anne Perótin-Dumon, sería muy absurdo, a la luz de la lectura de Alexis o El tratado del inútil combate, hablar de la masculinidad, pues como quedó demostrado, dicha construcción está predeterminada arbitrariamente y no puede considerarse como unívoca. Por este motivo, al finalizar el texto, se 
podría afirmar que Alexis - tras sufrir la crisis de masculinidad- comienza una nueva etapa: la construcción de su identidad.

Ahora bien, conviene detenerse a analizar la problemática inherente al constructo de 'identidad'. En primer lugar, al aludir a la construcción identitaria de Alexis no se pretende afirmar que él sustituye el modelo forzado de 'hombre' por el modelo 'gay'. No es tan sencillo, la cuestión va más allá de colocarse una etiqueta en la frente. En segundo lugar, es iluso pensar que existe una identidad como tal, y el sostenerlo adquiere un carácter irreal, puesto que existen miles de formas de concebirse como individuo, caminar, vestirse, hablar, pensar y vivir la sexualidad.

Tanto el heterosexual (que cree tenerlo todo bajo control y claramente definido) como el homosexual carecen de identidad. Y aunque el sistema patriarcal ha impuesto lo heterosexual como lo "normal” y 'lo masculino' y 'lo femenino' como lo "natural" para mantener la unidad y el poder a partir de la homogeneidad, esto es una falacia evidenciada en el tejido textual.

Por tanto, resultaría ingenuo postular la existencia de una identidad homosexual como tal, dado que ello equivaldría a afirmar una esencia del "ser gay" $y$, realmente, no hay una verdad natural y trashistórica de la homosexualidad.

Así, Foucault, al hablar de la identidad homosexual, apunta que se trata de un concepto cambiante, una construcción histórica, un producto de la historia y, por ende, puede ser modificada por la reinvención individual $\mathrm{y}$ colectiva.

Lo anterior significa que la identidad homosexual como tal no existe, no está dada, no es definitiva ni única. Por esta razón, Didier Eribon en Reflexiones sobre la cuestión gay (2001) insiste en que la autenticidad de una persona que se declara homosexual está en ser "para sí" y no "en sí". Es decir, no se trata de "ser" para los demás, sino "ser" sólo para sí mismo. No hay que demostrarle nada a la sociedad, porque son identidades personales que se crean a través de la recreación de las subjetividades.
Por esto, al finalizar el texto, Alexis deja planteada la posibilidad de reinventarse desde múltiples formas y de construirse a sí mismo. Se trata de moldear la subjetivación ${ }^{9}$ y crear "estilos de vida" donde se procure el desprendimiento de las mentalidades legadas de las estructuras sociales.

Justamente, la idea de separarse del sistema de sujeción nos conduce hacia la temática de la subjetivación y del estilo de vida: la construcción de una "cultura gay ${ }^{10 "}$. Para Eribon, la aceptación de la homosexualidad debe guiar al individuo hacia un nuevo sistema relacional: la cultura gay, la cual debe desarrollarse para escapar de los regímenes de la "normalidad".

Es imperioso reconocer que la forma de la sexualidad implica forzosamente una cultura, es decir, modos de expresión y valoraciones, las cuales son cambiantes en el tiempo. En este sentido, el comportamiento sexual es también la conciencia de lo que se hace, del modo en el cual se vive la experiencia y el valor que le atribuye a ésta. De esta manera, la conciencia de la homosexualidad trasciende la experiencia individual y alcanza un sentimiento que se inserta dentro de un grupo social determinado. "La conciencia individual y colectiva no sólo existe y se perpetúa a través de los siglos, sino que asimismo, "cambia con el tiempo y varía de un lugar a otro", y se puede, en consecuencia, transformarse y reinventarse..." (Eribon, 2001: 443).

En sí, todas estas premisas nos confirman que la novela no tiene un final, ya que la conclusión de la carta representa para Alexis el comienzo de una nueva vida. El texto queda abierto, no está terminado, al igual que la identidad de Alexis. Las identidades están por crearse. Es un proceso, por lo tanto, es un devenir como lo es la vida misma.

\section{A modo de conclusión}

Es terrible que el silencio pueda llegar a ser culpable (Yourcenar, 2000: 38)

Sin duda alguna, la lectura del texto de Marguerite Yourcenar constituye un envite a romper el silencio, pues éste no debe marcar 
el destino de las personas. Y es a partir de esta premisa que este texto francés avecina de manera, quizás prematura, el advenimiento de un discurso que cincuenta años después estaría en su apogeo.

La estructura textual, la introspección en el mundo del personaje y el abordaje de la temática homosexual le confiere al texto gran vigencia, ya que induce, desde una producción artística, el cuestionamiento incansable de un hecho social marcado por la represión y la discriminación.

La lectura de Alexis o El tratado del inútil combate (1929) realizada desde la noción de género propicia gran cantidad de elementos que eventualmente podrían enriquecer los estudios vinculados con las construcciones de las masculinidades. Esto es posible a través de las resignificaciones de las voces marginales. Es decir, no se trata de presentar por medio del género epistolar la vida íntima de un personaje o de generar fama mediante la polémica causada a raíz de la transgresión de las prohibiciones sociales. El alcance de una novela de esta índole supera toda expectativa de mercadeo, dado que persigue la multiplicación de los discursos para liberar a los sujetos de los corsés de la normalidad y los patrones inamovibles del patriarcado.

Así, la confesión de la homosexualidad de Alexis se convierte en una clara enunciación de la masculinidad en crisis, es decir, del desajuste de un modelo insostenible. La carta de Alexis a Mónica evidencia cómo el aparato opresor es capaz de acabar con la libertad de los sujetos hasta el punto de generar en ellos represión y culpabilidad.

Ahora bien, cuando Alexis logra aceptar su irreductible realidad, inicia un compromiso consigo mismo porque dejará de ser en función de la propuesta social. Es allí donde se deconstruye la idea de una masculinidad absoluta, puesto que el desapego a la norma implica la derrota del patriarcado y el triunfo de la masculinidades.

En este sentido, el texto permite la reapropiación de los significados producidos por el poder $\mathrm{y}$, a partir de esto, las identidades sexuales vienen a representar modos de vida distintos a los impuestos. En otros términos, elegir la sexualidad significa cambiar, revertir el modelo heterosexual y “(...) buscar la posibilidad de reinventarse y escapar de la sojuzgación que operan a las normas sociales" (Eribon, 2001: 430).

Son precisamente las razones anteriormente desarrolladas las que le confieren a esta novela un gran valor estético y literario y la convierten en antesala de discusiones posteriores en torno al tema de género, en específico, sobre la homosexualidad y la búsqueda de las masculinidades.

Ya lo decía Marguerite Yourcenar en su prólogo "Basta con mirar atentamente a nuestro alrededor para darnos cuenta de que el drama de Alexis y Mónica continúa viviéndose y continuará sin duda haciéndolo mientras el mundo de las realidades sensuales siga cuajado de prohibiciones" (Yourcenar, 2000: 15). Cabe señalar que la primera prohibición es hablar acerca de la homosexualidad, y aún cuando se dialogue al respecto, ello no implica la aceptación de la diferencia ni la abolición de la injuria y el rechazo. "Las costumbres, aunque se diga lo contrario, han cambiado demasiado poco para que la idea central de esta novela haya envejecido" (Yourcenar, 2000: 15).

Sin embargo, esta postura no es del todo desesperanzadora, pues remite al poder inmanente en la palabra, en el lenguaje mismo y, por ende, en la Literatura. Siendo así, los trabajos literarios producidos en todo el mundo deberán crear un espacio discursivo para estas voces marginales (incluidas aquí las mujeres, las lesbianas, los travestís y los bisexuales). El arte podría, en este sentido, ser el portavoz de las minorías y del contradiscurso de la oficialidad. $\mathrm{Y}$ aunque en América Latina se ha comenzado a trabajar en ello, con muchas resistencias, esta tarea no puede limitarse a contemplar una élite intelectual, es necesario que el tópico de la homosexualidad abarque campos como la política y la religión.

El reto está en hablar porque el silencio no puede ser culpable y en prestar atención a las producciones artísticas porque probablemente sea el único medio donde las voces acalladas emerjan, de ahí, la insistencia de que sean 
tomadas en consideración para trabajar asuntos de género.

Por último, conviene subrayar el gran valor que adquiere la relectura de textos anteriores a la producción contemporánea, pues, a partir de ésta es posible establecer conexiones que faciliten la impugnación de modelos, el cuestionamiento de la realidad dada como "natural" y "normal", pero sobretodo, la búsqueda de la multiplicidad de identidades y la posibilidad de reinvención. Y es quizás allí, donde la lectura de Alexis o El tratado del inútil combate no puede pasar inadvertida.

\section{Notas}

1. André Gide (1869-1951) escritor francés, cuyas novelas, obras de teatro y textos autobiográficos se caracterizan por su exhaustivo análisis de los esfuerzos individuales hacia la autorrealización y el empleo de conceptos éticos protestantes. Esto, sumado a los trabajos críticos, repercutieron en la Literatura y la Filosofía. En este caso, se alude a este autor, pues su conexión con la obra de Marguerite Yourcenar es inevitable, sobretodo porque ella lo menciona en su prólogo.

2. El término 'homosexualidad', en la época moderna, aparece cuando los psiquiatras describen en términos de orientación sexual del individuo lo que antes se consideraba como una práctica o acto. La homosexualidad se percibió como una patología mental o una perversión del deseo o del instinto. Según Havelock Ellis la palabra fue empleada en 1869 por un médico alemán; por esto, se afirma que el homosexual no existía antes de 1870 , porque era una invención de la psiquiatría. Lo que existía era la sodomía, un conjunto de prácticas que eran condenadas, mas el individuo homosexual no existía. De este modo, el concepto de homosexualidad responde a la formación histórica del individuo "anormal". Es así como surgen los sujetos y las subjetividades a partir de la sumisión a las "normas" y la exclusión. "Nadie se había considerado previsto de una "naturaleza" sexual particular antes de que la psiquiatría llegase a forjar su teatro conceptual" (Eribon 2001: 392).

Debe considerarse acá, para una mayor comprensión del término, el vínculo existente entre la locura y el homosexual, ya que a partir del S. XVII la locura va a ser motivo de exclusión, y con ella toda práctica que no se apegue a la norma. Las enfermedades mentales se asocian en aquella época al pecado, la sinrazón y la culpabilidad. Los homosexuales figuran dentro de los pecadores, por ello, sufren el destierro social y el encierro en los manicomios. Se establece un parangón entre razón / sinrazón, salud / enfermedad, normal / anormal.

Por su parte, esta investigación se alejará del concepto con el cual fue acuñado y entenderá la homosexualidad como una forma de asumir, pensar y vivir la sexualidad. Sin embargo, para completar esta referencia puede consultarse en Histoire de la folie á l'age classique de Michael Foucault, FCE. Madrid. 1997.

3. Cabe recordar que quizás esta impresión se deriva de la estrategia literaria utilizada por Marguerite Yourcenar, aspecto desarrollado en el Preludio textual.

4. Estos motivos se suman a la elección de la estrategia literaria empleada por Marguerite Yourcenar, aspecto tratado en las páginas anteriores.

5. La carta es enviada a una colectividad también porque ésta constituye el texto literario en sí, y como tal estará en circulación, por eso su contenido posee muchos destinatarios de épocas y lugares geográficos distintos.

6. En este apartado se alude a la metáfora del espejo, pero su mención no está vinculada, al menos directamente, con la teoría especular propuesta por Jacques Lacan, la cual ha sido ampliamente explotada dentro del discurso feminista.

7. Lo subrayado no pertenece al texto de Yourcenar.

8. En ambas citas se evidencia claramente una de las premisas que han determinado el desarrollo de esta investigación, la recurrencia a los hechos, discursos o textos del pasado para resignificarlos.

9. En términos de Gilles Delueze sería "la operación por la cual individuos o comunidades se construyen como sujetos, al margen de los saberes construidos y los poderes establecidos" (Eribon, 2001: 473).

10. Cabe advertir que el texto propiamente no hace referencia a la conformación de una "cultura gay", sin embargo, esto no implica que no pueda ser 
pensado o leído desde allí. Además, la propuesta subyace en la novela desde el instante en que Alexis confiesa su homosexualidad y decide, a partir de esto, reiniciar su vida. Así, a pesar de que la obra de Marguerite Yourcenar no lo exprese abiertamente en 1929, el planteamiento textual le cede un espacio a las actuales reflexiones en torno a la homosexualidad y las masculinidades. Por supuesto que esta lectura sólo es posible a través de la resignificación textual. Sumado a ello, al hablar de "cultura gay" debemos ubicar allí a aquellos sujetos moldeados por la historia de la homosexualidad, el sojuzgamiento y la resistencia, quienes tuvieron que crear espacios distintos y modos de vida para imprimir el cambio.

\section{Referencias bibliográficas}

Aponte, W. A. 2002. "El género y el lenguaje". http://www.genero/lenguaje34/aponte

Blot, J. D. 1980. Marguerite Yourcenar. Paris: Éditions Seghers.

Connell, R. W. 1995. Masculinities. Los Angeles: University of California Press.

Cortazzo, U. 2002. "Estampa de varón”. Arte, literatura y masculinidad. http://www. literaturavirtual.com/revista69/cortazo.

Edith, D. 2003. "El modelo de dominio de los varones, cuestionado. La crisis de la masculinidad, fin de la homofobia". http://www.edix.ac./varon/homofobia.

Eribon, D. 2001. Reflexiones sobre la cuestión gay. Barcelona: Ediciones Anagrama.

Freedman, R. 1972. La novela lírica Hermann Hesse, André Gide y Virginia Wolf.
Barcelona: Barral Editores S.A. Breve Biblioteca de Respuesta.

Giddens, A. 2000. Modernidad e identidad del yo: el yo y la sociedad en la época contemporánea. Barcelona: Ediciones Península.

González, J.C. 2001. "Género y masculinidad en Cuba: ¿el otro lado de la historia?". http:/cubaliteraria.com/letra joven/ juliocesarpages.hmt.

Hernández, A. 2001. “'Masculinidad o masculinidades?" La Tarea. Revista de Educación y Cultura. http://www.latarea. com.mx/articu8/hernandez8.

Kimmel, M. 2004. "La masculinidad y la reticencia al cambio". http://www. masculinities/magazine/n87.

Pérotin-Dumon, A. 2001. "El género en historia". Universidad Católica de Chile. Cap. IV. http://www.sas.ac.uk/ilas/genero.

Rosbo, P. 1972. Entretiens radiophoniques avec Marguerite Yourcenar. Paris: Éditions Mercure de France.

Sloan,Tod y Rubén Reyes J. 2000. "La construcción de la masculinidad". Antropología. Género e Masculinidades. http://www.artnet.com.br/marko/sloan.

Vargas Ruiz, R. 2003. Pétalos y espinas. Hombres gay, relaciones de pareja y violencia. Buenos Aires: Ediciones elaleph.com.

Yourcenar, Marguerite. 2002. Alexis o El tratado del inútil combate. España: Suma de Letras. 
